\title{
Performance of Arsi-Bale kids supplemented with graded levels of pigeonpea in dry season in Mid Rift valley of Ethiopia
}

\author{
Belete Shenkute $^{1 \star}$, Abubeker Hassen ${ }^{1}$, Abule Ebro $^{2}$ and Nura Amen ${ }^{3}$ \\ ${ }^{1}$ Department of Animal and Wildlife Sciences, University of Pretoria, Pretoria 0002, South Africa. \\ ${ }^{2}$ Oromia Agricultural Research Institute, Adami Tulu Research Centre, P. O. Box 35, Zeway, Ethiopia. \\ ${ }^{3}$ Sustainable Environment and Development Action (SEDA), Meki, Ethiopia.
}

Accepted 30 May, 2012

\begin{abstract}
Free grazing/browsing Arsi-Bale kids in dry season were supplemented with different levels of dried pigeon pea (Cajanus cajun) leaves to study its effect on weight gain. Kids browsed freely $\left(\mathrm{PP}_{0}\right)$, and/or supplemented with $66 \mathrm{~g}\left(\mathrm{PP}_{66}\right), 99 \mathrm{~g}\left(\mathrm{PP}_{99}\right)$ and $132 \mathrm{~g}\left(\mathrm{PP}_{132} \mathrm{PP}\right)$ of sun dried pigeon pea leaves. Supplementation significantly $(P<0.05)$ increased average daily gain of kids but there was no significant $(P<0.05)$ difference between kids supplemented with $\mathrm{PP}_{99}$ and $\mathrm{PP}_{132} \mathrm{~g}$ in terms of total weight gain. There was a significance difference among treatments for net profit and the highest net profit was obtained for $\mathrm{PP}_{99}$. Therefore, supplementing kid with $\mathrm{PP}_{99}$ dried pigeon pea leaves was found to be the most profitable level for rift valley kid under farmer condition in dry season.
\end{abstract}

Key words: Cajanus cajun, kids, weight gain.

\section{INTRODUCTION}

In mid-rift valley of Ethiopia, where the dry season covers over six months of the year, browsing and crops residues are the major source of nutrients consumed by goats in the dry seasons (EARO, 2000; Abule et al., 2003; Alemayehu, 2003). In these months, the existing feeds are low in protein and high in fiber content, which in turn can limit their feeding value for goats (Van Soest, 1982). According to McDonald et al. (1988), when goats depend on such low quality diet voluntary feed intake and digestibility are low. Consequently, animal performance is poor due to lack of adequate dietary protein and energy intake. In addition, lack of substantial nutrient supply from the feed to a body of the kids might increase susceptibility to disease and parasites (Markos, 2006; Getahun, 2008). This in turn leads to stunted growth and lower market weight of the kids within a reasonable time frame. To mitigate the problem, a number of strategies have been tested in the past to improve the protein and energy nutrient supply in the rumen in order to create suitable environment for optimum fermentation and maximum microbial protein synthesis. Practically this can be achieved using agro-industrials by products such as oil seed cakes and forage legumes that can serve as a protein supplement depending on the farmer economic levels. Of this, adapted multipurpose trees can be used as cheap source of protein supplements to improve the utilization of poor quality dry pasture and crop residues.

Pigeon pea has a better $\mathrm{N}$-fixing ability even in its unfertilized condition (Myaka et al., 2006). Pigeon pea is well adapted to the climate and uniquely combines

*Corresponding author. E-mail: beletegemeda@gmail.com. 
Optimal nutritional profiles, high tolerance to environmental stresses, high biomass productivity, most nutrient and moisture contributions to the soil. It is widely used as fodder and feed for livestock. Its foliage is an excellent fodder with high nutritional value (Onim et al., 1985). Therefore, this experiment was set up to measure the growth responses of Arsi-Bale kids to graded levels of supplementation and identify optimum level that is biologically and economically profitable.

\section{MATERIALS AND METHODS}

\section{Description of the study area}

The experiment was conducted at the Adami Tulu Agricultural Research Center, located at 1,650 m above sea level (m.a.s.l.) in the rift valley of Ethiopia in the south direction from the Addis Ababa (the capital city). It has an average annual rainfall that rarely exceeds 700 $\mathrm{mm}$ and its mean minimum and maximum temperatures are 14 and $27^{\circ} \mathrm{C}$, respectively. The area has a soil type of fine sandy loam with sand: silt: clay in the ratio of $34: 38: 18$, respectively, with a pH of 7.88 (Abule et al., 1998).

\section{Experimental animals and treatments}

Total of 32 Arsi-Bale weaned kids with similar weight were randomly allocated to four groups of eight kids. Arsi-Bale goats are one of the distinct breed types in Ethiopia, which are distributed though out highlands of Arsi, Bale, Sidamo and Western Hararghae zones (Figure 1). They are compact, medium in size and light in color that enabled them to adapt well to harsh environment and predominantly exists in the mid rift valley (the study area) of Ethiopia (FARM-Africa, 1996). These kids were drenched for internal parasites and sprayed for external parasites. Each group received randomly one of the following four treatments. The treatments were: grazing/ browsing $\left(\mathrm{PP}_{0}\right)$ for $8 \mathrm{~h}$, and/or supplemented with 66,99 and $132 \mathrm{~g}$ of sun dried leaves of pigeonpea. The supplements at $\mathrm{PP}_{66}, \mathrm{PP}_{99}$ and $\mathrm{PP}_{132}$ were intended to provide 20,30 and $40 \%$ of the total dry matter intake of the kids. The equivalent absolute oven dry mater values were 60, 90 and 120 for $\mathrm{PP}_{66}, \mathrm{PP}_{99}$ and $\mathrm{PP}_{132}$ respectively. All mineral licks were provided in the feeding trough and clean water was provided during the day time to all kids.

Kids in the control group stayed in the field during the day time while during the night they were sheltered in their pens. Kids in the treatment groups were placed in their respective supplemental feed after $8 \mathrm{~h}$ browsing and throughout the night in their feeding pens. Left over were collected and put in separate plastic bucket near each treatment and weighed every next morning. The supplemental feeds were weighed and placed in their respective treatment levels before the kids returned at 2 PM. The experiment lasted for 90 days. The weight of the kids was taken every week after overnight fasting.

Pigeon pea leaves were harvested from trial site of forage research unit of the center. The re-growths were harvested at about 10 to 12 weeks on three occasions, sun dried and stored for feeding trials. Fresh samples and collected seeds were also taken during each cutting and oven dried for $65^{\circ} \mathrm{C}$ for $72 \mathrm{~h}$ and stored to compare the differences in chemical composition.

\section{Determination of chemical composition}

Composite samples of fresh leaves, sundried leaves (leftover) and seeds were studied for chemical composition. The oven dried samples were ground in a Willey Mill to pass through $1 \mathrm{~mm}$ sieve for the determination of chemical composition. Feed samples were analyzed for DM and ash using the method of AOAC (2000). Nitrogen was determined using the micro-Kejeldhal method (AOAC, 2000). Crude Protein (CP) was calculated as $N \times 6.25$. The Neutral Detergent Fibre (NDF), Acid Detergent Fibre (ADF) and Acid Detergent Lignin (ADL) were analyzed according to Van Soest et al. (1991).

\section{Economic analysis}

Gross margin analysis was used to determine the profitability of the treatments. As there is no market price for pigeonpea leaf biomass, its cost was taken as the cost of producing maize on the same land. The value of weight gain (output) was calculated by multiplying the dressing percentage of the kids (50\%) and the price of goat meat at the time of the study.

\section{Statistical analysis}

Feed intake, body weight changes and profit gained were analyzed for the treatment differences using (SAS, 2000) General Linear Model procedures. Mean differences were considered significant at $\mathrm{P}<0.05$ and mean separation among treatments was done using the Duncan's Multiple Range Tests. The model used was:

$Y_{i j}=\mu+T_{i}+e_{i j}$

Where; $Y_{i j}=$ response variables such as average daily gain (ADG), DM intake, feed conversion ratio (FCR), profits; $\mu=$ overall mean; $T_{i=}$ effect of the $i^{\text {th }}$ dietary treatment; $e_{i j}=$ random error.

\section{RESULTS AND DISCUSSION}

\section{Chemical composition}

The chemical compositions of leaves and seeds were shown in Table 1. There is no significant $(\mathrm{P}<0.05)$ difference in chemical composition between fresh and sun dried leaves except the DM, while chemical composition of the seed was observed to be significantly $(P<0.05)$ higher in CP and total ash (mineral content) than leaves. The CP contents of the leaves and seeds were in a range of values reported by Swaminathan and Jain (1973) while up to $30 \%$ has been also reported in other closely related species (Reddy et al., 1979). According to Van Soest (1982), high fiber content in forages is the primary factor limiting feed intake; however, pigeonpea has relatively lower fiber content than other multipurpose trees. Furthermore, anti-nutritional factors and poly-phenols are less problematic in pigeonpea (Faris and Singh, 1990). Pigeonpea is widely used as fodder and feed for livestock (Rao et al., 2002) due to its excellent fodder with high nutritional value and higher digestibility (Onim et al., 1985). The seeds can also used as animal feed (Wallis et al., 1986) and are a rich source of carbohydrates, minerals and vitamins for human food (Damaris, 2007). It can be a good supplementary food especially for the protein deficient parts of Africa either as a sole diet or mixed with other dishes. 

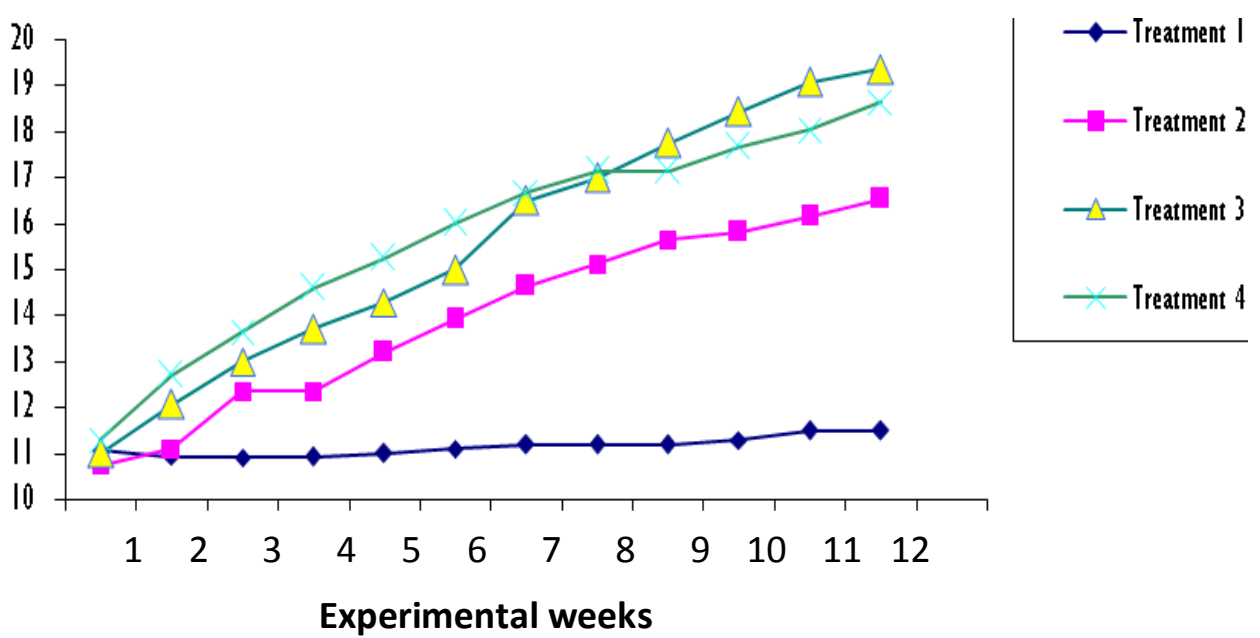

Experimental weeks

Figure 1. Trends in weight gain of kids fed on experimental feed.

Table 1. Mean (SD) Chemical composition (\%DM basis) of the fresh, sun dried and seed of pigeonpea.

\begin{tabular}{lccc}
\hline Compositions & Pigeonpea leaves (fresh) & Pigeonpea leaves (dried) & Pigeonpea seeds \\
\hline DM & $44.5 \pm 0.31^{\mathrm{c}}$ & $94.5 \pm 0.36^{\mathrm{a}}$ & $86.9 \pm 0.06^{\mathrm{b}}$ \\
Ash & $9.12 \pm 0.10^{\mathrm{c}}$ & $9.45 \pm 0.05^{\mathrm{b}}$ & $14.5 \pm 0.09^{\mathrm{a}}$ \\
CP & $22.3 \pm 0.05^{\mathrm{b}}$ & $21.3 \pm 0.5^{\mathrm{c}}$ & $23.9 \pm 0.1^{\mathrm{a}}$ \\
NDF & $33.2 \pm 0.03^{\mathrm{b}}$ & $33.8 \pm 0.03^{\mathrm{b}}$ & $41.5 \pm 0.13^{\mathrm{a}}$ \\
ADF & $29.5 \pm 0.05^{\mathrm{a}}$ & $29.4 \pm 0.07^{\mathrm{a}}$ & $17.44 \pm 0.05^{\mathrm{b}}$ \\
Lignin & $10.12 \pm 0.12 \mathrm{a}$ & $10.01 \pm 0.7 \mathrm{a}$ & - \\
Cellulose & $12.86 \pm 0.23 \mathrm{a}$ & $12.9 \pm 0.7 \mathrm{a}$ & - \\
\hline
\end{tabular}

${ }^{a b}$ Means in the same row for each parameter with different superscripts are significantly different $(p<0.05)$.

\section{Feed intake and weight changes}

There were significant $(P<0.05)$ differences in intake of dried Cajanus cajun leaves among the treatments (Table 2). The highest feed intake was observed for kids offered with $\mathrm{PP}_{120}$ followed by $\mathrm{PP}_{90}$. Supplementation of dried peagon pea leaves has resulted in increase in weight gain of kids. The highest weight gain was observed for kids that received $\mathrm{PP}_{120}$ and $\mathrm{PP}_{90}$ but there was no significant $(P<0.05)$ differences between them. The result of the study conducted by incorporating pigeon pea in mixture with cassava peel based diets showed a generally enhanced intake in West Africa dwarf goat (Ahamefule et al., 2006). According to Bonsi et al. (1994), the positive effects of supplementation on feed intake may have been a reflection of the increase in the intake of essential nutrients such as energy, vitamins, minerals and in particular nitrogen $(\mathrm{N})$. Leguminous fodder trees, as supplements, alleviate $\mathrm{N}$ deficiency thereby improving the rate of degradation of the basal diet and the fractional rate of liquid matter from the rumen and hence feed intake. Moreover, leguminous fodder trees increase protein supply to the host animal by increasing the supply of both degradable and un-degradable protein, and by creating a favorable rumen environment resulting in enhanced fermentation of the basal roughage and thus increased microbial protein synthesis (Osuji et al., 1995).

The improvement in weight gain (growth) of kids supplemented with dried pigeon pea is associated with higher $\mathrm{N}$ contents of pigeonpea leaves. In other supplementation study using pigeonpea leaves in animals' diet, it was noted that it increases the intake of low quality herbage resulting in high animal live weight (Karachi and Zengo, 1998). According to Pamo et al. (2002), almost twice weight gain was observed for kids' supplemented during the dry season than the un-supplemented due to the protein level in the multipurpose trees which was 84 to $140 \%$ higher than in the grasses. This clearly justifies the use of pigeonpea as feed supplements in ruminant nutrition during periods of forage scarcity. By-products of split and shriveled seeds are used as livestock feed and as an inexpensive alternative to high cost animal feed sources such as bone meal and fish meal (Chisowa, 2002). The production of adequate quantities of good quality dry season forage to supplement crop residues and pasture roughages is the only way to economically 
Table 2. Mean (SD) feed intake, weight gain and profit obtained of experimental kids.

\begin{tabular}{lcccc}
\hline \multirow{2}{*}{ Parameter } & \multicolumn{4}{c}{ Treatment } \\
\cline { 2 - 5 } & $\mathbf{P P}_{\mathbf{0}}$ & $\mathbf{P P}_{66}$ & $\mathbf{P P}_{\mathbf{9 9}}$ & $\mathbf{P P}_{\mathbf{1 3 2}}$ \\
\hline Feed offered (pigeonpea leaves) & & & & \\
On DM basis (g/kid/day) & 0 & 60 & 90 & 120 \\
Sundried basis (g/kid/day) & 0 & 66 & 99 & 132 \\
& & & & \\
Feed intake (pigeonpea leaves) & & $47.09 \pm 0.09^{\mathrm{c}}$ & $64.89 \pm 0.11^{\mathrm{b}}$ & $72.21 \pm 0.12^{\mathrm{a}}$ \\
Sundried basis (g/kid/day) & & & & \\
& & & & \\
Weight gain & & & & \\
Initial wt/head (kg) & $11.07 \pm 0.18^{\mathrm{a}}$ & $10.82 \pm 1.53^{\mathrm{a}}$ & $11.28 \pm 0.16^{\mathrm{a}}$ & $11.28 \pm 0.99^{\mathrm{a}}$ \\
Final weight /head (kg) & $11.50 \pm 0.5^{\mathrm{c}}$ & $16.53 \pm 1.8^{\mathrm{b}}$ & $19.35 \pm 0.95^{\mathrm{a}}$ & $18.64 \pm 2.43^{\mathrm{a}}$ \\
Total weight gain/head (g) & $0.42 \pm 0.12^{\mathrm{c}}$ & $6.11 \pm 0.2^{\mathrm{b}}$ & $8.06 \pm 0.18^{\mathrm{a}}$ & $7.36 \pm 1.2^{\mathrm{a}}$ \\
Average daily gain (g/kid/day) & $4.93 \pm 0.6^{\mathrm{d}}$ & $70.2 \pm 0.15^{\mathrm{c}}$ & $92.7 \pm 0.12^{\mathrm{a}}$ & $84.6 \pm 0.9^{\mathrm{b}}$ \\
\hline ab Means in the same row for each parameter with different superscripts are significantly different $(\mathrm{p}<0.05)$. &
\end{tabular}

Table 3. Cost and economic return for Arsi-Bale kids fed on dried pigeonpea leaves.

\begin{tabular}{lcccc}
\hline \multirow{2}{*}{ Item } & \multicolumn{3}{c}{ Treatment } \\
\cline { 2 - 5 } & $\mathbf{P P}_{\mathbf{0}}$ & $\mathbf{P P}_{66}$ & $\mathbf{P P}_{\mathbf{9 9}}$ & $\mathbf{P P}_{\mathbf{1 3 2}}$ \\
\hline Number of animals per treatment & 7 & 7 & 7 & 7 \\
Average live weight (kg) at purchase per head & 11.07 & 10.82 & 11.08 & 11.08 \\
Average purchase price (ETB) per head & 43.71 & 43.11 & 43.00 & 43.28 \\
Average operational cost per kid (feed cost + labour + medicament) & 0.35 & 6.89 & 8.18 & 12.88 \\
Total body weight gain in kg of live weight & 11.5 & 16.53 & 19.35 & 18.64 \\
Average selling price per kid & 47.28 & 67.85 & 70.7 & 70.7 \\
Average return (gross return)/head (ETB) & $5.57 \pm 1.98^{\mathrm{c}}$ & $24.71 \pm 1.25^{\mathrm{b}}$ & $29.28 \pm 0.95^{\mathrm{a}}$ & $29.42 \pm 0.97^{\mathrm{a}}$ \\
Net profit/head (ETB) & $5.22 \pm 1.98^{\mathrm{c}}$ & $17.82 \pm 1.25^{\mathrm{b}}$ & $21.10 \pm 0.95^{\mathrm{a}}$ & $16.21 \pm 0.95^{\mathrm{a}}$ \\
\hline
\end{tabular}

${ }^{a b}$ Means in the same row for each parameter with different superscripts are significantly different $(p<0.05)$.

overcome the dry season feed shortage by small scale farmers in developing countries.

\section{Economical analyses}

The results of economic analyses are shown in Table 3. The analysis revealed that all treatments in the study were profitable; however, there is a significant difference between the supplemented and the un-supplemented group with higher profit for the supplemented kids. Among supplemented groups there is no significance difference between $\mathrm{PP}_{99}$ and $\mathrm{PP}_{132}$ although both has more profitable than $\mathrm{PP}_{66}$. There was a little increase in weight for the un-supplemented kids that also reflected in their profit, though the lower profitability mainly attributed to the limited weight gain due to protein shortage for growth. Within the supplemented group, however, the highest profit was recorded for the kids that received $\mathrm{PP}_{99}$ and $\mathrm{PP}_{132}$ than $\mathrm{PP}_{66}$. This is because there is no significant $(P<0.05)$ difference in weight gain between kids that received $\mathrm{PP}_{99}$ and $\mathrm{PP}_{132}$. Supplementation of kids with $\mathrm{PP}_{99}$ is more economical than $\mathrm{PP}_{132}$. The results from the gross margin analysis described as net profit also indicates that weight gain was the main determining factor in the gross margin. This suggests that weight gains over the feeding periods relatively played an important role in the determination of profitability of growing animals that is mainly affected by protein supplementation. In current price trend scenario where the prices of inputs (drug and concentrate) is linearly increasing and that makes the supplementation of concentrate feed unaffordable under small scale farmers, it is possible to have substantial increase profit by supplementing with $C$. cajun leafs.

In Sub-Saharan regions where there is a critical protein shortage, one way by which farmers might increase profitability is by supplementing their kids with nitrogen rich browses. The profitability of producing such feeds should also be viewed from different aspects; reducing cost of purchase of concentrate, reducing cost of fertilizer to improve soil fertility, contribution to increase carbon stock by carbon sequestration, increase protein and 
mineral sources (seed) as human food and increase income by selling seeds ( $1 \mathrm{~kg}$ of seed was sold for 40 ETB by time of study).

\section{Conclusion}

Under farmers' condition where kids freely browse in dry season, it is possible to increase their weight gain by supplementing dried leaves of pigeonpea at $99 \mathrm{~g}$ per head per day. This level provides about $30 \%$ of the total dry matter intake. Under the current condition in Ethiopia, the use of pigeonpea is advantageous especially when there is high demand for forage seed and farmers can benefit from both leaves and seeds sell.

\section{ACKNOWLEDGEMENT}

The authors gratefully thank Tafari Benchamo and Badiru Roba who had assisted the team in data collection and animal management. We extend our acknowledgement for Oromia Agricultural Research Institute (OARI) for funding the work and Adami Tulu Research Center for logistic support.

\section{REFERENCES}

Abule E, Gremew E, Aliye H (1998). Adami Tulu Agricultural research Center, Bulletin No.1, Oromia Agricultural Development Bureau, Fifnfine, Ethiopia.

Abule E (2003). Rangeland evaluation in relation to pastoralists perceptions in the Middle Awash Valley of Ethiopia. A PhD thesis Presented to the University of the Free State, Bloemfontein, South Africa. P. 297.

Ahamefule FO, Ibeawuchi JA, Ibe SN (2006). Nutrient Intake and Utilization of Pigeon Pea-Cassava Peel Based Diets by West African Dwarf (WAD) Bucks. Pak. J. Nutr. 5:419-424.

Alemayehu M (2003). Country pasture/Forage resources profiles: Ethiopia. Food and Agriculture Organization of the United Nations (FAO). Web site: http://www.fao.org/ag/agp/agpc/doc/counprof/ ethiopia/ethiopia.htm(accessed on $10^{\text {th }}$ April, 2011)

AOAC (Association of Official Analytical Chemists) (2000). Official methods of analysis (15th ed.). Inc., Washington D.C., USA.

Bonsi MLK, Osuji PO, Nsahlai IV, Tuah AK (1994). Graded levels of Sesbania sesban and Leucaena leucocephala as supplements to teff straw given to Ethiopian Menz sheep. Anim. Prod. 59:235-244.

Chisowa DM (2002). Comparative evaluation of performance of growing rabbits fed Leucaena leucocephala-cereal basal diet supplemented with legume grains. MSc Thesis, University of Malawi, Bunda College of Agriculture.

Damaris OA (2007). The potential of pigeonpea (Cajanus cajan (L.) Millsp.) in Africa. Nat. Resour. Forum 31:297-305.

EARO (Ethiopian Agricultural Research Organization) (2000). National Small Ruminants Research Strategy Document. EARO, Addis Ababa, Ethiopia.

Faris DG, Singh U (1990). Pigeonpea: Nutrition and products. In: Nene, Y.L., Hall, S.D., Sheila, V.K. (Eds.). The Pigeonpea. Wallingford, UK. CAB International.

FARM-Africa (1996). Goats types of Ethiopia and Eritrea; Physical Description and management systems. Farm Africa/International Livestock Research Institute, Addis Ababa, Ethiopia.
Getahun L (2008). Productive and Economic performance of Small Ruminant production in production system of the Highlands of Ethiopia. Ph.D.dissertation, University of Hohenheim, StuttgartHoheinheim, Germany.

Karachi M, Zengo M (1998). Legume forages from pigeonpea, leucaena and sesbania as supplements to natural pastures for goat production in western Tanzania. Agrofores. Syst. 39:13-21.

Markos T (2006). Productivity and Health of indigenous sheep Breeds and Crossbreds in the Central Ethiopian Highlands. Faculty of Medicine and Animal Science, Department of Animal Breeding and Genetics. Ph.D.dissertation, Swedish University of Agricultural Sciences, Uppsala, Sweden.

McDonald PRA, Edward JF, Greenhalg D (1988). Animal Nutrition Longman Scientific and technical, New York.

Myaka FM, Sakala WD, Adu-Gyamfi JJ, Kamalongo D, Ngwira N, Odgaard R, Nielsen NE, Høgh-Jensen H (2006). Yields and accumulation of $\mathrm{N}$ and $\mathrm{P}$ in farmer-managed intercrops of maizepigeonpea in semi-arid Africa. Plant Soil 285:207-220.

Onim JFM, Semenye PP, Fitzhugh HA (1985). Research on feed resources for small ruminants on smallholder farms in Western Kenya. In: Kategile, J.A., Said, A.N., Dzowela, B.H. (Eds.), Animal Feed Resources for Small-scale Livestock Producers, Proceedings of the second PANESA workshop, held in Nairobi, Kenya, 11-15 November 1985.

Osuji PO, Fernandez-Rivera S, Odenyo AA (1995). Improving fiber utilization and protein supply in animals fed poor quality roughages: ILRI nutrition research and plans. In: Rumen Ecology Research Planning. Proceedings of a Workshop Held at ILRI, Addis Ababa, Ethiopia, 13-18 March 1995. pp. 1-22.

Pamo TE, Tendonkeng F, Kadjio JTT, Kwami HN, Taboum RK, Kana JR, Tegodjeu A (2002). Evaluation of the comparative growth and reproductive performance of West African dwarf goat in the western highland of Cameroon, Proceedings of the Final Review Meeting of an IAEA Technical Co-operation Regional AFRA Project Organized by the Joint FAO/IAEA Division of Nuclear Techniques in Food and Agriculture on Development and Field Evaluation of Animal Feed Supplementation Packages Cairo, Egypt, November 25-29, 2000 (2002), pp. 87-96.

SAS (2000). SAS User's guide: Statistics. Cary, North Carolina: SAS institute

Swaminathan MS, Jain HK (1973). Food legumes in Indian agriculture. In: Milner, M.M. (Ed.). Nutritional Improvement of Food Legumes by Breeding. Proceedings of a symposium sponsored by PAG, held at FAO, Rome, Italy, 3-5 July 1972. PAG of the United Nations System, United Nations, New York. pp. 69-82.

Rao SC, Coleman SW, Mayeux HS (2002). Forage production and nutritive value of selected pigeonpea ecotypes in the southern great plains, Crop Sci. 42:1259-1263.

Reddy LJ, Green JM, Bisen SS, Singh U, Jambunathan R (1979). Seed protein studies on Cajanus cajan L., Atylosia spp, and some hybrid derivatives. In: Seed Protein Improvement in Cereals and Grain Legumes. IAEA/FAO, Neuherberg 2:105-117.

Wallis ES, Faris DG, Elliot R, Byth DE (1986). Varietal improvement of pigeonpea for small-holder livestock production systems. Proceedings of workshop on Crop Livestock SystemsResearch, July 7-11 1986, Khon Kaen, Thailand.

Van Soest PJ (1982). Nutritional ecology of ruminants. O and B books, Inc. Oregon, USA.

Van Soest PJ, Robertson JB, Lewis BA (1991). Methods for dietary fiber, neutral detergent fiber and non-starch polysaccharides in relation to animal nutrition. Dairy Sci. 74:3587-3597. 